\title{
Impact of coronary flow on the risk of microvascular obstruction in acute myocardial infarction
}

\author{
Nadine Abanador-Kamper ${ }^{1 *}$, Lars Kamper ${ }^{2}$, Vasiliki Karamani ${ }^{1}$, Patrick Haage ${ }^{2}$, Melchior Seyfarth ${ }^{1}$ \\ From 19th Annual SCMR Scientific Sessions \\ Los Angeles, CA, USA. 27-30 January 2016
}

\section{Background}

Microvascular obstruction (MO) and coronary flow have been independently described to have a high prognostic impact in patients after acute myocardial infarction. The interdependence of these facts has not been elucidated, so far. Aim of this study was to investigate the impact of preand post-interventional coronary flow on the occurrence of $\mathrm{MO}$ in patients with acute myocardial infarction.

\section{Methods}

336 patients with acute myocardial infarction were examined by cardiac magnetic resonance imaging after primary percutaneous coronary intervention. Patients were categorised into two groups based on the presence or absence of MO. Procedural characteristics and marker of infarct size were included in the analysis.

\section{Results}

MO was present in 110 (33\%) and absent in $226(67 \%)$ patients. In the univariate comparison both groups differed significantly regarding age, sex, the qualifying event, pre- and post-interventional thrombolysis in myocardial infarction (TIMI) flow, as well as parameters of infarct size. However, after multivariable regression analysis preinterventional TIMI-flow 0, proximal culprit lesion, postinterventional TIMI-flow <III and CK-MB remained strong independent predictors for MO. Odds ratios for these factors were 2.31 (95\% CI 1.04-5.11, $P=0.034$ ) for pre-interventional TIMI-flow 0 , for proximal culprit lesion 11.94 (95\% CI 5.70-25.01, $P<0.001$ ), for post-interventional TIMI-flow III 0.28 (95\% CI 0.10-0.74, $P=0.010)$ and for CK-MB 1.50 (95\% CI 1.24-1.82, $P<0.001)$.

'Department of Cardiology, Witten/Herdecke University, Helios Medical Centre, Wuppertal, Germany

Full list of author information is available at the end of the article

\section{Conclusions}

Pre-interventional proximal coronary artery occlusion (TIMI 0) and insufficient post-interventional coronary reperfusion (TIMI-flow <III) have a high impact on the occurrence of MO in acute myocardial infarction. Furthermore patients with MO show significant higher markers of infarct size.

\section{Authors' details}

${ }^{1}$ Department of Cardiology, Witten/Herdecke University, Helios Medical Centre, Wuppertal, Germany. ${ }^{2}$ Department of Diagnostic and Interventional Radiology, Witten/Herdecke University, Helios Medical Centre Wuppertal, Wuppertal, Germany.

Published: 27 January 2016

doi:10.1186/1532-429X-18-S1-P93

Cite this article as: Abanador-Kamper et al:: Impact of coronary flow on the risk of microvascular obstruction in acute myocardial infarction. Journal of Cardiovascular Magnetic Resonance 2016 18(Suppl 1):P93.

Submit your next manuscript to BioMed Central and take full advantage of:

- Convenient online submission

- Thorough peer review

- No space constraints or color figure charges

- Immediate publication on acceptance

- Inclusion in PubMed, CAS, Scopus and Google Scholar

- Research which is freely available for redistribution 